\title{
RESPONSE OF MAIZE (ZEA MAYS L.) TO RIMSULFURON UNDER SALT CONDITIONS
}

\author{
ElżBIETA SaCAŁA, ANNA DEMCZUK, TOMASZ MichalsKi \\ Department of Plant Physiology, University of Agriculture \\ Cybulskiego 32, 50-205 Wroclaw, Poland \\ e-mail: sacala@ozi.ar.wroc.pl
}

(Received: March 5, 2002. Accepted: January 30, 2003)

\begin{abstract}
Investigations were carried out to determine the possible interaction between salinity $\left(60 \mathrm{mmol} \cdot \mathrm{dm}^{-3} \mathrm{NaCl}\right)$ and phytotoxicity of herbicide Titus $25 \mathrm{DF}$ (sulfonylurea herbicide containing active ingredient rimsulfuron). The herbicide was added to the nutrient solution at two concentrations -1 or $100 \mathrm{nmol} \cdot \mathrm{dm}^{-3}$. After 7 days of cultivation in the nutrient solution determined were the growth parameters and some biochemical compounds (photosynthetic pigments, total protein and free amino compounds content). The combined action of $1 \mathrm{nmol} \cdot \mathrm{dm}^{-3} \mathrm{rimsulfu}-$ ron and salt caused a reduction in plant biomass accumulation, but this reduction was due to the salt itself. In the presence of $100 \mathrm{nmol} \cdot \mathrm{dm}^{-3}$ rimsulfuron, growth inhibition of maize roots was very high and salinity did not modify herbicide toxicity. However, reduction in maize shoots growth equalled the sum of the reductions caused by each particular factor applied separately (additive effect). The reduction in shoot fresh weight reached 64\%.

The investigated stress factors induced a significant increase in amino compounds, with the exception of maize roots grown under $\mathrm{NaCl}$ plus $100 \mathrm{nmol} \cdot \mathrm{dm}^{-3}$ rimsulfuron. The concentration of total protein in maize roots diminished under $\mathrm{NaCl}$ and $100 \mathrm{nmol} \cdot \mathrm{dm}^{-3}$ rimsulfuron, although in the other cases, it did not change distinctly in comparison to the control. All factors, with the exception of $\mathrm{NaCl}$, induced a slight increase in protein contents in maize leaves. Stress factors did not change significantly the total chlorophyll concentration, however, carotenoid content was markedly reduced. Nevertheless, the combined action of $100 \mathrm{nmol} \cdot \mathrm{dm}^{-3}$ rimsulfuron and $\mathrm{NaCl}$ caused a $10 \%$ increase in carotenoid content as compared to the control plants.

In conclusion, salinity did not change the toxicity of the herbicide applied in low dose $\left(1 \mathrm{nmol} \cdot \mathrm{dm}^{-3}\right)$, but it did increase herbicide toxicity at high concentration $\left(100 \mathrm{nmol} \cdot \mathrm{dm}^{-3}\right)$ regarding the maize shoots.
\end{abstract}

KEY WORDS: sulfonylureas, rimsulfuron, salinity, maize, growth reduction, photosynthetic pigments, protein.

\section{INTRODUCTION}

Herbicides are used extensively in agriculture, they are efficient tools in reducing the weeds and improve the yields and quality of crops. Generally, action and metabolism of herbicides are well established, but there is little information on the influence of environmental conditions on action of herbicides (Mazur and Falco 1989). Thus, an important question arises, whether environmental factors can modify herbicides' phytotoxicity. A few researches indicate that environmental factors influence the efficiency of herbicides (Dickson et al. 1990; Sahid et al. 1996; Undabeytia et al. 1996). Soil salinity is an important factor limiting agricultural productivity in many parts of the world. Therefore, there is a need for more knowledge on interaction of herbicides with salinity.

Sulfonylurea herbicides represent a new generation of herbicides used at low rates (in grams per hectare) and show a very low toxicity to animals. These herbicides inhi- bit the activity of acetolactate synthase (ALS), the enzyme that catalyzes the first step in the biosynthesis of the branched amino acids - valine, leucine and isoleucine - and then alter protein metabolism (Ray 1984). It has been well documented that sulfonylureas reduce the availability of branched amino acid in treated plants, nevertheless the consequence of that reduction is an increase in the other amino acids (Royuela et al. 1991; Scarponi et al. 1995; Fayez and Kristen 1996). It is worthy of mention, that a low level of branched amino acids does not exert an inhibitory effect on protein accumulation in some plants (Clayton and Reynolds 1991).

The objective of this study was to determine the extent at which salinity modifies maize response to Titus $25 \mathrm{DF}-$ sulfonylurea herbicide (with a. i. - active ingredient rimsulfuron - N-[[(4,6-dimethoxy-2-pyrimidinyl)amino]carbonyl]-3-(ethylsulfonyl)-2-pyridinesulfonamide). Considering the role of salinity in Titus toxicity to maize, we examined the growth parameters (fresh and dry weight, 
length) and some biochemical constituents, i.e. photosynthetic pigments, total protein and free amino compounds. All tested biochemical compounds are important components of stress-coping mechanisms (Lichtenthaler 1996). Generally, maize is tolerant to sulfonylurea herbicide, but there are differences in tolerance among their cultivars (Demczuk 1996). For our experiments we had chosen two doses of herbicide: subinhibitory concentration of $1 \mathrm{nmol} \cdot \mathrm{dm}^{-3}$ a.i. and concentration of $100 \mathrm{nmol} \cdot \mathrm{dm}^{-3}$ a.i. effectively applied to weed control.

\section{MATERIAL AND METHODS}

Maize (Zea mays L. var. Kometa, seeds were obtained from "Nasiona Kobierzyc" Company) after germination (48 h) was grown in beakers filled with the following media: modified Knop solution (control), Knop solution with the addition of $60 \mathrm{mmol} \cdot \mathrm{dm}^{-3} \mathrm{NaCl}$ (salt treatment), rimsulfuron at concentration of 1 or $100 \mathrm{nmol} \cdot \mathrm{dm}^{-3}$ (herbicide treatments) and both $60 \mathrm{mmol} \cdot \mathrm{dm}^{-3} \mathrm{NaCl}$ and rimsulfuron (salt and herbicide treatments). Culture conditions were as follows: $16 \mathrm{~h}$ photoperiod $\left(220 \mu \mathrm{mol} \cdot \mathrm{m}^{-2} \cdot \mathrm{s}^{-1}\right)$ at $26 / 20^{\circ} \mathrm{C}$ day/night temperature, $65-70 \%$ relative humidity. After 7 days of cultivation in the nutrient solution plant growth was determined (shoot and root length, fresh and dry weight) as well as total protein content, free amino compounds and photosynthetic pigments.

The contents of protein and free amino acids were determined in dry plant material. Plants organs (shoots and roots) were dried for $2 \mathrm{~h}$ at $105^{\circ} \mathrm{C}$ and than for $48 \mathrm{~h}$ at $70^{\circ} \mathrm{C}$. Plant samples $(50 \mathrm{mg}$ of whole roots or second and third leaf) were homogenized in $7 \mathrm{~cm}^{-3}$ of $5 \%$ trichloroacetic acid (TCA) and centrifuged $15 \mathrm{~min}$ at $18000 \mathrm{~g}$. After centrifugation the supernatant was adjusted to $\mathrm{pH} 5.5 \div 7.0$ and amino compounds were determined using the ninhydrine reagent (Weber et al. 1991). The pellet obtained after first centrifugation was dissolved in $1 \mathrm{~mol} \cdot \mathrm{dm}^{-3} \mathrm{NaOH}$ and stored for $10 \mathrm{~min}$ at $100^{\circ} \mathrm{C}$. Than the aliquots were centrifuged $(10 \mathrm{~min}$ at $18000 \mathrm{~g})$ and $\mathrm{NaOH}$-soluble protein in supernatant was determined by the Bradford's method (1976) with bovine serum albumin (BSA) as the standard. The experiments were repeated six times.

Photosynthetic pigments were extracted from the second leaf of maize using $80 \%$ acetone and the concentrations of chlorophylls and carotenoids were calculated using Arnon equations (1949). The experiments were repeated three times.

All mean values were analysed statistically and the least significant difference (LSD, $\mathrm{p}<0.05)$ was used for means comparisons.

\section{RESULTS}

\section{Plant growth (Fig. 1)}

Salt stress and herbicide at concentration of $100 \mathrm{nmol} \cdot \mathrm{dm}^{-3}$ led to significant inhibition in shoot and root growth of maize, but $\mathrm{NaCl}$ did not inhibit roots lengths. Rimsulfuron at concentration of $1 \mathrm{nmol} \cdot \mathrm{dm}^{-3}$ did not significantly change the growth parameters of maize. Salt plus $1 \mathrm{nmol} \cdot \mathrm{dm}^{-3}$ herbicide caused inhibition of plant growth, but that inhibition was due to the salt. $\mathrm{NaCl}$ plus $100 \mathrm{nmol} \cdot \mathrm{dm}^{-3}$ herbicide led to the most significant decrease in maize growth. The shoots were less sensitive than roots to herbicide alone, as well as to herbicide plus $\mathrm{NaCl}$. In the case of shoots the combined effect of $\mathrm{NaCl}$ and herbicide was additive. The reduction of shoot fresh weight reached $38 \%$ and $25 \%$ respectively for salt condition and in the presence of $100 \mathrm{nmol} \cdot \mathrm{dm}^{-3}$ rimsulfuron, whereas under $\mathrm{NaCl}$ plus herbicide it amounted to $64 \%$. The decrease in dry weight of maize shoots, grown in nutrient solution with the addition of $\mathrm{NaCl}$ plus $100 \mathrm{nmol} \cdot \mathrm{dm}^{-3}$ herbicide was very high, but not as high as the reduction in fresh weight, which ranged up to $51 \%$. Root growth was dramatically inhibited by the herbicide at concentration of $100 \mathrm{nmol} \cdot \mathrm{dm}^{-3}$, whereas $\mathrm{NaCl}$ caused a lower inhibition of root growth. In the presence of $100 \mathrm{nmol} \cdot \mathrm{dm}^{-3}$ herbicide the root length amounted only to $31 \%$ of the control, and fresh and dry weight were $18 \%$ and $29 \%$ of the control respectively. Combined action of $\mathrm{NaCl}$ and $100 \mathrm{nmol} \cdot \mathrm{dm}^{-3}$ herbicide caused the greatest inhibition of growth, but the differences between herbicide and $\mathrm{NaCl}$ plus herbicide treatments remained insignificant.

\section{Protein and amino compound contents (Fig. 2A, 2B)}

All stress factors led to the increase in total protein content and free amino compounds level in maize leaves. Both concentrations of herbicide and herbicide plus $\mathrm{NaCl}$ caused approximately a $20 \%$ increase in protein level, as compared to control plant. $\mathrm{NaCl}$ did not change significantly the protein content in leaves, but it caused a 2.8-fold increase in amino compounds. The remaining stress factors also augmented accumulation of amino compounds, but these changes were less significant than under $\mathrm{NaCl}$ stress. The concentration of total protein in maize roots decreased under $\mathrm{NaCl}$ and $100 \mathrm{nmol} \cdot \mathrm{dm}^{-3}$ rimsulfuron, but it was not significantly altered under $1 \mathrm{nmol} \cdot \mathrm{dm}^{-3}$ rimsulfuron and herbicide plus $\mathrm{NaCl}$. All stress treatments caused a cosiderable increase in amino compounds level in maize roots, with the exception of $100 \mathrm{nmol} \cdot \mathrm{dm}^{-3}$ rimsulfuron plus $\mathrm{NaCl}$. The highest increase in free amino compounds was observed in the presence of $1 \mathrm{nmol} \cdot \mathrm{dm}^{-3}$ rimsulfuron and $1 \mathrm{nmol} \cdot \mathrm{dm}^{-3}$ rimsulfuron plus $\mathrm{NaCl}$ and it amounted approximately to $250 \%$ of the control.

\section{Photosynthetic pigments (Fig. 2C)}

The changes in total chlorophyll content were limited. However, carotenoid concentration was markedly reduced by all investigated stress factors. Nevertheless, the combined action of $100 \mathrm{nmol} \cdot \mathrm{dm}^{-3}$ rimsulfuron and $\mathrm{NaCl}$ caused a $10 \%$ increase in carotenoid content, as compared to the control plants.

\section{DISCUSSION}

To determine the influence of salinity on rimsulfuron phytotoxicity, we analysed the growth parameters and some biochemical constituents such as total protein, free amino compounds and photosynthetic pigments. The growth response to sulfonylurea herbicides shows that maize var. Kometa is tolerant to rimsulfuron when applied at low concentration. In the presence of low concentration of rimsulfuron $\left(1 \mathrm{nmol} \cdot \mathrm{dm}^{-3}\right)$ plus $\mathrm{NaCl}$ there is no interaction between herbicide and salinity, and maize growth inhibition is due to $\mathrm{NaCl}$. At high concentration of rimsulfuron 

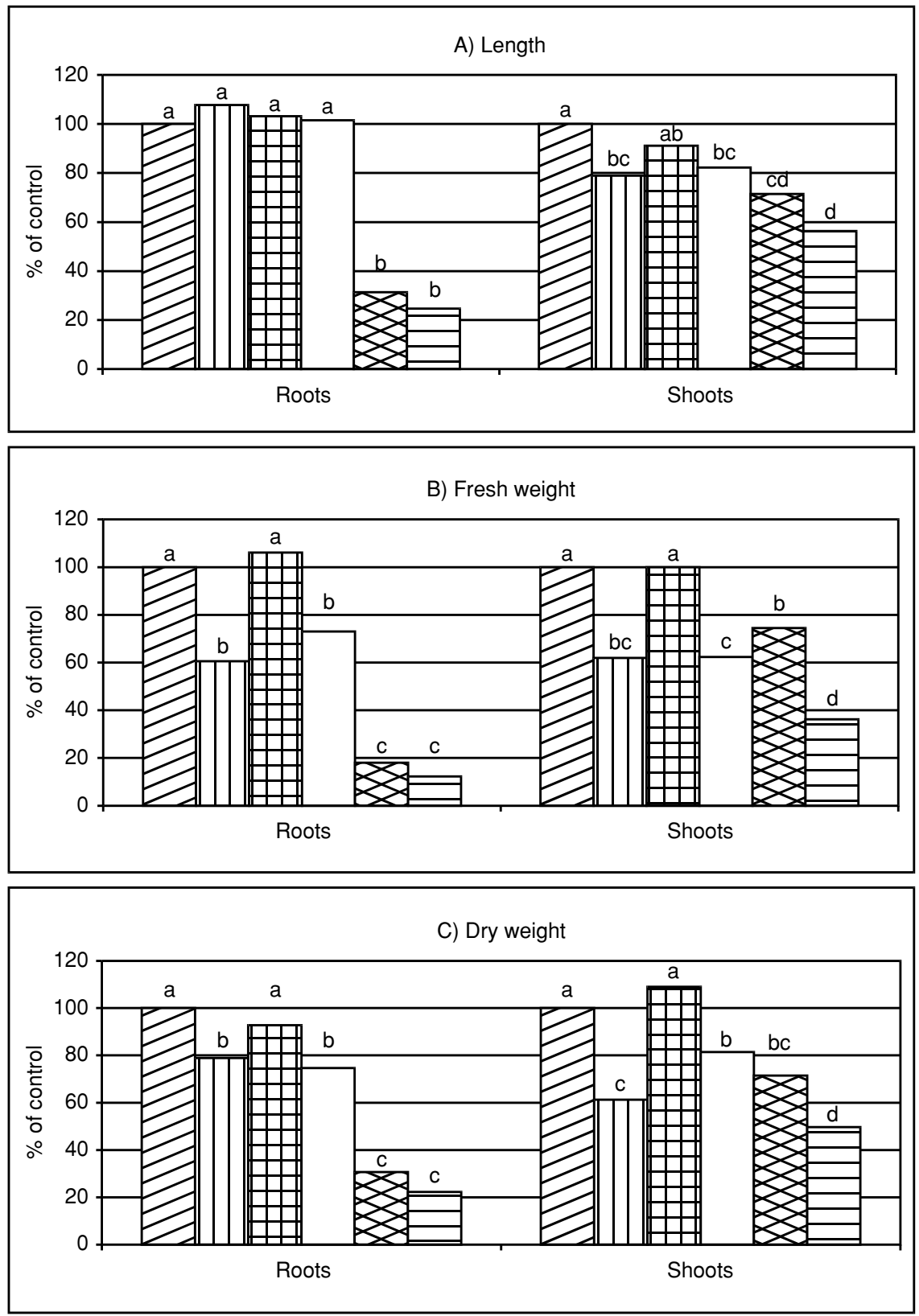

\begin{tabular}{|lll|}
\hline control & 悲 $\mathrm{NaCl}$ & 聿 $1 \mathrm{nM}$ rimsulfuron \\
$\square 1 \mathrm{nM}$ rimsulfuron $+\mathrm{NaCl}$ & $100 \mathrm{nM}$ rimsulfuron & 目 $100 \mathrm{nM}$ rimsulfuron $+\mathrm{NaCl}$ \\
\hline
\end{tabular}

Differences between control and stress treatments were compared by LSD and values marked with the same letter do not differ significantly $(5 \%)$.
Fig. 1. The influence of $60 \mathrm{mmol} \mathrm{dm}^{-3} \mathrm{NaCl}$, 1 and $100 \mathrm{nmol} \mathrm{dm}^{-3}$ rimsulfuron and $\mathrm{NaCl}$ plus rimsulfuron on length (A), fresh weight (B) and dry weight $(\mathrm{C})$ of roots and shoots in maize after 7 days of treatment. $\left(100 \mathrm{nmol} \cdot \mathrm{dm}^{-3}\right)$ the growth of maize is markedly reduced. Root growth is more reduced than shoot growth. This result is often observed if herbicides are applied to the nutrient solution (Royuela et al. 1991; Demczuk 1996; Sacała et al. 1999). Reduction in dry weight of shoot reached $29 \%$, whereas the drop of root dry weight was $71 \%$. Considerable reduction of root growth in the presence of sufonylurea herbicides was observed in many plants - maize, wheat, bean, pea, broad bean (Royuela et al. 1991; Fayez and Kristen 1996). If $100 \mathrm{nmol} \cdot \mathrm{dm}^{-3}$ rimsulfuron was applied under salt conditions, the strongest inhibition in root and shoot growth was observed. The changes in length and fresh weight of shoots indicate that the combined effect of
$\mathrm{NaCl}$ and rimsulfuron on maize is additive - the total response equals the sum of the particular factors. Reduction in fresh weight of shoot amounted to 38 and $25 \%$ in the presence of $\mathrm{NaCl}$ and rimsulfuron respectively. However, in the presence of $\mathrm{NaCl}$ plus rimsulfuron, it was $64 \%$. In our previous study we showed that the inhibitory effect of $\mathrm{NaCl}$ plus glyphosate (a nonselective herbicide which inhibits aromatic amino acids biosynthesis) on shoot growth in maize was more significant than the inhibition due to each of the factor used separately (Sacała et al. 1999). Considering the combined action of $100 \mathrm{nmol} \cdot \mathrm{dm}^{-3}$ rimsulfuron and $\mathrm{NaCl}$ on root growth, no similar correlations were found. In this case, the reduction of root growth was very high and 

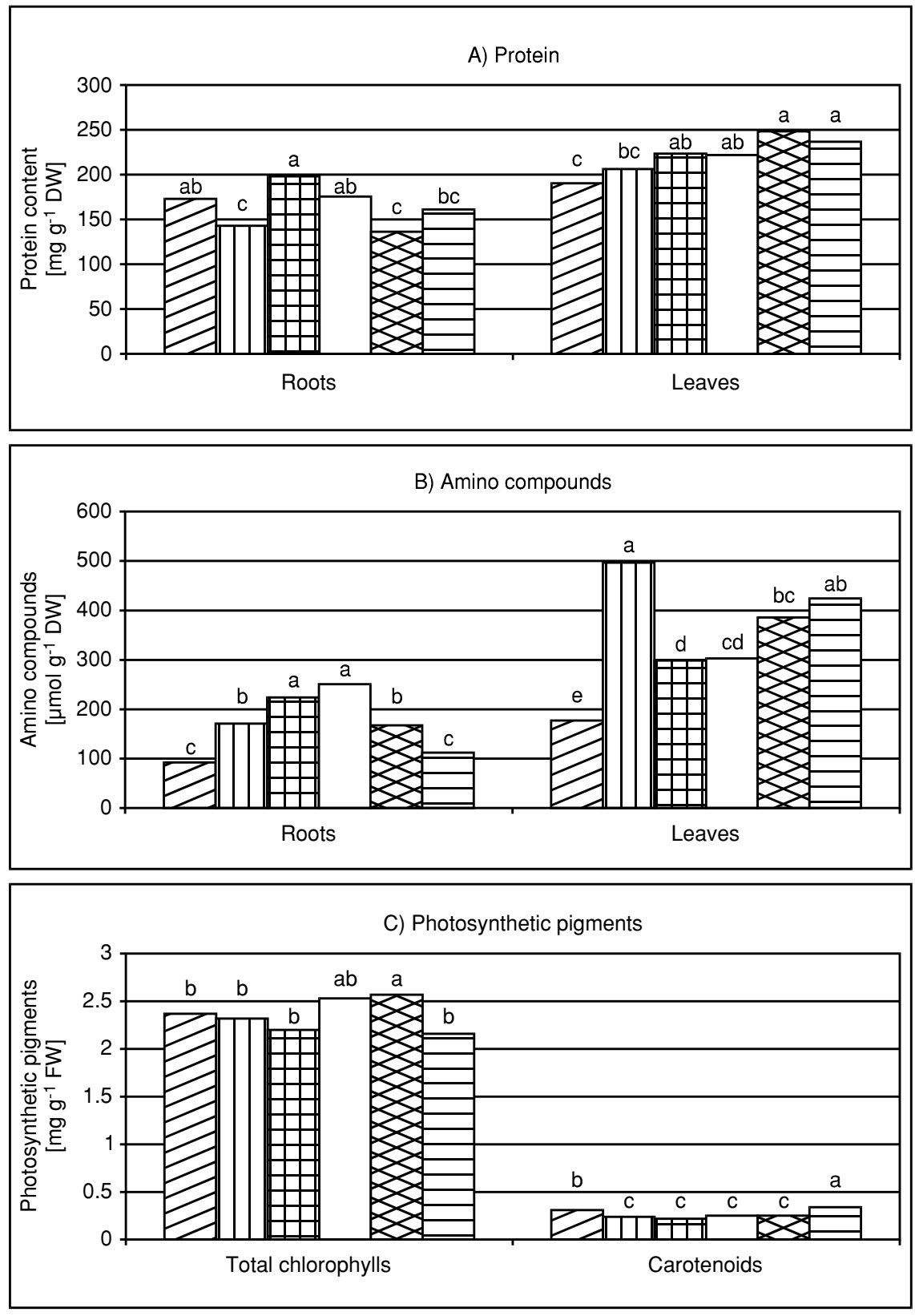

\begin{tabular}{|lll|}
\hline control & 悲 $\mathrm{NaCl}$ & 围 $1 \mathrm{nM}$ rimsulfuron \\
$\square 1 \mathrm{nM}$ rimsulfuron $+\mathrm{NaCl}$ & $100 \mathrm{nM}$ rimsulfuron & 目 $100 \mathrm{nM}$ rimsulfuron $+\mathrm{NaCl}$ \\
\hline
\end{tabular}

Differences between control and stress treatments were compared by LSD and values marked with the same letter do not differ significantly $(5 \%)$.
Fig. 2. The influence of $60 \mathrm{mmol} \mathrm{dm}^{-3} \mathrm{NaCl}$, 1 and $100 \mathrm{nmol} \mathrm{dm}^{-3}$ rimsulfuron and $\mathrm{NaCl}$ plus rimsulfuron on total protein content (A), free amino compounds (B) and photosynthetic pigments $(\mathrm{C})$ in maize after 7 days of treatment. was caused by rimsulfuron. Rimsulfuron at $100 \mathrm{nmol} \cdot \mathrm{dm}^{-3}$ concentration is very toxic to maize roots. Similar results were obtained for cucumber (Kuc et al. 2002). This is not surprising, because sulfonylurea herbicides drastically inhibit cell divisions in roots (Ray 1982; Rost 1984; Clayton and Reynolds 1991). Fayez and Kristen (1996) suggest that the herbicide-induced root growth reduction may be partially due to the injuries of root caps.

The data regarding biochemical constituents indicate that the investigated stress factors led to significant changes in total protein and free amino compound contents. Rimsulfuron applied at 1 and $100 \mathrm{nmol} \cdot \mathrm{dm}^{-3}$ concentration caused a marked increase in protein and amino compound level in leaves and in amino compound contents in maize roots. However, $100 \mathrm{nmol} \cdot \mathrm{dm}^{-3}$ rimsulfuron led to a decrease in root protein concentration. Rimsulfuron, like the other sulfonylurea herbicides, reduces the concentration of branched amino acids in the total amino acid pool. Nevertheless, there are reports indicating the increase in total free amino acid contents of plant treated with sulfonylureas (Royuela et al. 1991). Our data show that the most significant increase in free amino acid contents appeared in leaves of maize grown under $\mathrm{NaCl}$ stress. This high accumulation of free amino compounds may contribute to the osmoregulation and protection of proteins and membranes in conditions of salt stress (Delauney and Verma 1993; Ha- 
segawa et al. 2000). Accumulation of soluble nitrogen compounds in response to environmental stresses seems to be a widespread phenomenon (Levy 1983; Delauney and Verma 1993; Costa and Morel 1994; Gzik 1996; Gilbert et al. 1998; Aziz et al. 1999; Hasegawa et al. 2000; Sacała et al. 2002). Among these compounds free amino acids play an important role. The analysis of total protein content indicates that accumulation of free amino compounds is not associated with protein degradation. An increase in total protein content in leaves may be due to synthesis and accumulation of "stress proteins" (Clayton and Reynolds 1991; Riccardi et al. 1998; Scott-Craig et al. 1998; Campalans et al. 1999; Hasegawa et al. 2000). In maize roots, a high concentration of free amino compounds was observed in the presence of $1 \mathrm{nmol} \cdot \mathrm{dm}^{-3}$ rimsulfuron and $1 \mathrm{nmol} \cdot \mathrm{dm}^{-3}$ rimsulfuron plus $\mathrm{NaCl}$, whereas $100 \mathrm{nmol} \cdot \mathrm{dm}^{-3}$ rimsulfuron plus $\mathrm{NaCl}$ had no effect. An increase in free amino compounds under $100 \mathrm{nmol} \cdot \mathrm{dm}^{-3}$ rimsulfuron appears to be a consequence of protein proteolysis. The fall of total protein content under this condition supports that suggestion.

The total chlorophyll concentrations for all treatments did not change considerably, while the carotenoid content decreased significantly. These results support the conclusion that carotenoids are more sensitive to the investigated stressors than chlorophylls. It is possible that stress factors, which do not directly affect the synthesis of chlorophylls, reduce chlorophyll contents in the long run (Lichtenthaler 1996; Younis et al. 2000). The combined action of 100 $\mathrm{nmol} \cdot \mathrm{dm}^{-3}$ rimsulfuron and $\mathrm{NaCl}$ caused a significant increase in carotenoid content. That unexpected increase displayed an antagonistic effect of interaction between salinity and herbicide. The marked increase in carotenoid contents in the presence of $\mathrm{NaCl}$ plus herbicide was observed in maize and cucumber (Sacała et al. 1999; Kuc 2002). It is well known that carotenoids are an important component of the antioxidative system in plants (Burton and Ingold 1984; Siefermann-Harms 1987). This oxidative stress in plant cells may be due to many different abiotic factors (Scandalios 1993).

\section{CONCLUSIONS}

Our experiments were performed to determine the possible interaction between herbicide phytotoxicity and salinity. These interactions might be considered as an increase or a decrase in herbicide toxicity to plants. In our experiments the definite tendencies in the combined action of rimsulfuron and $\mathrm{NaCl}$ were not recorded. This study indicates that salinity does not change the toxicity of the herbicide applied in a low dose $\left(1 \mathrm{nmol} \cdot \mathrm{dm}^{-3}\right)$. A high dose of herbicide $\left(100 \mathrm{nmol} \cdot \mathrm{dm}^{-3}\right)$ was very toxic to maize roots and, under combined action of herbicide and $\mathrm{NaCl}$, the inhibitory effect was caused by the herbicide itself. However, in the case of maize shoots, the negative effect of $\mathrm{NaCl}$ plus herbicide equalled the sum of negative effects exerted by each component applied separately (additive effect).

\section{LITERATURE CITED}

ARNON D.I. 1949. Copper enzymes in isolated chloroplasts. Plant Physiol. 34: 1-15.
AZIZ A., MARTIN-TANGUY J., LARHER F. 1999. Salt stressinduced proline accumulation and changes in tyramine and polyamine levels are linked to ionic adjustment in tomato leaf disc. Plant Science 145: 83-91.

BRADFORD M.M. 1976. A rapid and sensitive method for the quantification of microgram quantities of protein utilising the principle of protein dye binding. Anal. Biochem. 72: 248-254.

BURTON G.W., INGOLD K.U. 1984. $\beta$-karoten: un unusual type of lipid antioxidant. Science 224: 569-573.

CAMPALANS A., MESSEGUER R., GODAY A., PAGESS M. 1999. Plant responses to drought, from ABA signal transduction events to the action of induced proteins. Plant Physiol. Biochem. 37: 327-340.

CLAYTON D.S., REYNOLDS T.L. 1991. Chlorsulfuron effects on protein synthesis and accumulation in cultured root tips of Pisum sativum L. J. Plant Physiol. 137: 337-341.

COSTA G., MOREL J.-L. 1994. Water relations, gas exchange and amino acid content in Cd-treated lettuce. Plant Physiol. Biochem. 32: 561-570.

DELAUNEY A.J., VERMA D.P.S. 1993. Proline biosynthesis and osmoregulation in plants. Plant J. 4: 215-223.

DEMCZUK A. 1996. Wpływ herbicydów sulfonylomocznikowych na różne genotypy kukurydzy (Influence of sulfonylurea herbicides on various maize inbreeds). Zeszyty Naukowe Akademii Rolniczej we Wrocławiu, Rolnictwo LXVII, 300: 9-37 (in Polish with English summary).

DICKSON R.L., ANDREWS E.L., FIELD R.J., DICKSON E.L. 1990. Effect of water stress, nitrogen, and giberelic acid on fluazifop and glyphosate activity on oats (Avena sativa). Weed Science 38: 54-61.

FAYEZ K.A., KRISTEN U. 1996. The influence of herbicides on the growth and proline content of primary roots and on the ultrastructure of root caps. Environ. Exp. Bot. 36: 71-81.

GILBERT G.A., GADUSH M.V., WILSON C., MADORE M.A. 1998. Amino acid accumulation in sink and source tissues of Coleus blumei Benth. during salinity stress. J. Exp. Botany 318: 107-114.

GZIK A. 1996. Accumulation of proline and pattern of $\alpha$-amino acids in sugar beet plants in response to osmotic, water and salt stress. Environ. Exp. Botany 36: 29-38.

HASEGAWA P.M., BRESSAN R.A., ZHU J-K., BOHNERT H.J. 2000. Plant cellular and molecular responses to high salinity. Annu. Rev. Plant Physiol. Plant Mol. Biol. 51: 463-490.

KUC P., DEMCZUK A., SACAŁA E. 2002. Fitotoksyczność herbicydu Titus 24 DF dla ogórka w warunkach zasolenia (Phytotoxicity of sulfonylurea herbicide Titus $25 \mathrm{DF}$ in cucumber under saline environment conditions). Zeszyty Problemowe Postępów Nauk Rolniczych 481: 453-458 (in Polish with English summary).

LEVY D. 1983. Water deficit enhancement of proline and $\alpha$-amino nitrogen accumulation in potato plants and its association with susceptibility to drought. Physiol. Plant. 57: 169-173.

LICHTENTHALER H.K. 1996. Vegetation stress: an introduction to the stress concept in plants. J. Plant Physiol. 148: 4-14.

MAZUR B.J., FALCO S.C. 1989. The development of herbicide resistant crops. Annu. Rev. Plant Physiol. Plant Mol. Biol. 40: 441-470.

RAY T.B. 1982. The mode of action of chlorsulfuron: a new herbicide for cereals. Pestic. Biochem. Physiol. 18: 10-17.

RAY T.B. 1984. Site of action of chlorsulfuron. Plant Physiol. 75: 827-831.

RICCARDI F., GAZEAU P., DE VIENNE D., ZIVY M. 1998. Protein changes in response to progressive water deficit in maize. Plant Physiol. 117: 1253-1263.

ROST T.L. 1984. The comparative cell cycle and metabolic effects of chemical treatments on root tip meristem. III. Chlorsulfuron. J. Plant Growth Regul. 3: 51-63.

ROYUELA M., ARRESE-IGOR C., MUNOZ-RUEDA A., GONZALEZ-MURUA C. 1991. In vitro and in vivo effects of 
chlorsulfuron in sensitive and tolerant plants. J. Plant Physiol. 139: 235-239.

SACAŁA E., DEMCZUK A., GRZYŚ E. 1999. Fitotoksyczność herbicydu Roundup w warunkach zasolenia (Phytotoxicity of Roundup herbicide under saline environment conditions). Zeszyty Prob. Post. Nauk Rol. 469: 473-480 (in Polish with English summary).

SACAŁA E., DEMCZUK A., GRZYŚ E., SOBCZAK A. 2002. The effects of salt stress on growth and biochemical parameters in two maize varities. Acta Soc. Bot. Pol. 71: 101-107.

SAHID I.B., KADRI R.B.I., KADRI S. 1996. Effects of watering frequency, shade and glyphosate application on Paspalum conjugatum Berg (sour grass). Crop Protection 15: 15-19.

SCANDALIOS J.G. 1993. Oxygen stress and superoxide dismutases. 101: 7-12.

SCARPONI L., ALLA M.M.L., MARTINETTI L. 1995. Consequences on nitrogen metabolism in soybean (Glycine max L.) as a result of imazethapyr action on acetohydroxy acid synthase. J. Agric. Food Chem. 43: 809-814.
SCOTT-CRAIG J.S., CASIDA J.E., PODUJE L., WALTON J.D. 1998. Herbicide safener-binding protein of maize. Plant Physiol. 116: 1083-1089.

SIEFERMANN-HARMS D. 1987. The light-harvesting and protective function of carotenoids in photosynthetic membranes. Physiol. Plant. 69: 561-568.

UNDABEYTIA T., CHESHIRE M.V., McPHAIL D. 1996. Interaction of herbicide glyphosate with copper in humic complexes. Chemosfere 32: 1245-1250.

WEBER M.B., SCHAT H., TEN BOOKUM-VAN DER MAAREL. 1991. The effect of copper toxicity on the contents of nitrogen compounds in Silene vulgaris (Moench) Garcke. Plant and Soil 133: 101-109.

YOUNIS M.E., EL-SHAHABY O.A., ABO-HAMED S.A., IBRACHIM A.H. 2000. Effects of water stress on growth, pigments and ${ }^{14} \mathrm{CO}_{2}$ assimilation in three sorghum cultivars. Agr. Crop Science 185: 73-82.

\author{
REAKCJA KUKURYDZY (ZEA MAYS L.) \\ NA RIMSULFURON W WARUNKACH ZASOLENIA
}

\title{
STRESZCZENIE
}

Badania prowadzono w celu stwierdzenia czy istnieją interakcje pomiędzy zasoleniem $\left(60 \mathrm{mmol} \cdot \mathrm{dm}^{-3} \mathrm{NaCl}\right)$ a fitotoksycznością herbicydu Titus 25 DF (herbicyd sulfonylomocznikowy, substancja aktywna - rimsulfuron). Herbicyd stosowano w dwóch stężeniach $\left(1 \mathrm{i} 100 \mathrm{nmol} \cdot \mathrm{dm}^{-3}\right)$ i dodawano bezpośrednio do pożywki. Po siedmiu dniach wzrostu roślin w pożywce określono parametry wzrostowe roślin oraz zawartość podstawowych składników takich jak: barwniki fotosyntetyczne, białko całkowite oraz wolne związki aminowe.

Równoczesne działanie $1 \mathrm{nmol} \cdot \mathrm{dm}^{-3}$ rimsulfuronu i $\mathrm{NaCl}$ spowodowało redukcję biomasy roślin, jednak obniżka ta wynikała $\mathrm{z}$ obecności soli. Rimsulfuron o stężeniu $100 \mathrm{nmol} \cdot \mathrm{dm}^{-3}$ spowodował drastyczne zahamowanie wzrostu korzeni, obecność soli nie miała większego wpływu. Natomiast w przypadku pędów kukurydzy zahamowanie ich wzrostu pod wpływem łącznego działania $\mathrm{NaCl}$ i $100 \mathrm{nmol} \cdot \mathrm{dm}^{-3}$ rimsulfuronu było równe sumie procentowych zahamowań wzrostu spowodowanych pojedynczym czynnikiem, jest to więc oddziaływanie addytywne. Redukcja świeżej masy pędów kukurydzy wyniosła aż 64\%.

Czynniki stresowe spowodowały duży wzrost zawartości związków aminowych w badanych tkankach, wyjątek stanowiły korzenie kukurydzy rosnącej w obecności $\mathrm{NaCl}$ plus $100 \mathrm{nmol} \cdot \mathrm{dm}^{-3}$ rimsulfuron. Zawartość białka całkowitego w korzeniach kukurydzy obniżyła się w obecności $\mathrm{NaCl}$ oraz $100 \mathrm{nmol} \cdot \mathrm{dm}^{-3}$ rimsulfuronu, zaś pod wpływem pozostałych czynników nie zmieniała się znacząco. Wszystkie czynniki, z wyjątkiem $60 \mathrm{~mol} \cdot \mathrm{dm}^{-3} \mathrm{NaCl}$, indukowały niewielki wzrost zawartości białka w liściach kukurydzy. Pod wpływem badanych czynników zawartość chlorofilu nie zmieniała się znacząco natomiast stężenie karotenoidów obniżało się. Jednak łączne działanie $100 \mathrm{nmol} \cdot \mathrm{dm}^{-3}$ rimsulfuronu i $\mathrm{NaCl}$ spowodowało $10 \%$ wzrost zawartości karotenoidów.

Podsumowując można stwierdzić, że fitotoksyczność rimsulfuronu stosowanego w niskiej dawce $\left(1 \mathrm{nmol} \cdot \mathrm{dm}^{-3}\right)$ nie zmienia się w warunkach zasolenia natomiast wysokie stężenie $\left(100 \mathrm{nmol} \cdot \mathrm{dm}^{-3}\right)$ staje się bardziej toksyczne w stosunku do części nadziemnych kukurydzy.

SŁOWA KLUCZOWE: sulfonylomoczniki, rimsulfuron, zasolenie, kukurydza, zahamowanie wzrostu, barwniki fotosyntetyczne, białko. 